\title{
The "Prediflood" database of historical floods in Catalonia (NE Iberian Peninsula) AD 1035-2013, and its potential applications in flood analysis
}

\author{
M. Barriendos ${ }^{1,2}$, J. L. Ruiz-Bellet ${ }^{3}$, J. Tuset ${ }^{4}$, J. Mazón ${ }^{5}$, J. C. Balasch ${ }^{3}$, D. Pino ${ }^{5,6}$, and J. L. Ayala ${ }^{7}$ \\ ${ }^{1}$ Catalan Institute of Climate Sciences, Barcelona, Spain \\ ${ }^{2}$ Department of Modern History, University of Barcelona, Barcelona, Spain \\ ${ }^{3}$ Department of Environment and Soil Sciences, University of Lleida, Lleida, Spain \\ ${ }^{4}$ RIUS Fluvial Dynamics Research Group, Forest Science Centre of Catalonia, Solsona, Spain \\ ${ }^{5}$ Universitat Politècnica de Catalunya-BarcelonaTech, Barcelona, Spain \\ ${ }^{6}$ Institute of Space Studies of Catalonia (IEEC-UPC), Barcelona, Spain \\ ${ }^{7}$ Arxiu del Comú, Departament de Cultura i Turisme, Comú d'Andorra, Andorra la Vella, Andorra
}

Correspondence to: M. Barriendos (mbarriendos@ub.edu)

Received: 7 May 2014 - Published in Hydrol. Earth Syst. Sci. Discuss.: 11 July 2014

Revised: 10 October 2014 - Accepted: 18 October 2014 - Published: 4 December 2014

\begin{abstract}
Prediflood" is a database of historical floods that occurred in Catalonia (NE Iberian Peninsula), between the 11 th century and the 21st century. More than 2700 flood cases are catalogued, and more than 1100 flood events. This database contains information acquired under modern historiographical criteria and it is, therefore, suitable for use in multidisciplinary flood analysis techniques, such as meteorological or hydraulic reconstructions.
\end{abstract}

\section{Introduction}

Floods have always been among the most destructive of natural hazards, in part due to the traditionally high exposure and vulnerability of most human settlements. Indeed, between 1998 and 2009, Europe suffered more than 213 severe floods, which caused 1126 casualties, the displacement of half a million people and more than EUR 60 billion in economic losses (EEA, 2010).

Unfortunately, both the frequency and magnitude of floods are likely to increase in the near future due to climate change, thus worsening the effects of floods on the human population. This is especially true for the Mediterranean region, where climatic models foresee an increase of rainfall irregularity: in Catalonia (NE Iberian Peninsula), for the period 2070-
2100 , models estimate a $15 \%$ decrease in total rain depth but, at the same time, a $15-30 \%$ increase in the number of days with heavy precipitation (Barrera and Cunillera, 2011). In central Europe, torrential precipitation will also increase in the near future, although this cannot be assured to cause an increase in river flows, due to the short length of the data series (IPCC, 2014; Kovats and Valentini, 2014).

The increase of flood hazard will force the undertaking of protection measures, which are going to need information about flood frequency and magnitude. Unfortunately, river flow instrumental series are usually too short (when they exist at all) to analyse low-frequency events, such as flash floods (Gaume et al., 2009). However, these series can be lengthened with historical flood information. In this sense, the European Union Floods Directive on the assessment and management of flood risks (2007/60/EC of the European Parliament and of the Council, 26 November 2007) encourages the use of historical information in flood risk assessment.

Regrettably, historical flood compilations in Spain have always had a low quality, due to the lack of proper historiographical methods and, hence, they are useless in flood risk assessment. In fact, in order to ensure a good quality of information, historical flood compilations in Spain should be created anew. 
The main objective of this paper is to present the "Prediflood" database, a new database of historical floods in Catalonia that encompasses the period AD 1035-2013, created from scratch with modern historiographical methods; a secondary objective is to show its potential applications in flood analysis and in flood risk assessment. More specifically, this paper describes the process of creation of the "Prediflood" database from past events, the issues that can be improved and the potential of the organized information. The initial research project (see acknowledgements), in which this work was framed, analyses the past 500 years but data collection has provided information beyond this limit. This process is an opportunity to reassess previous procedures and to incorporate historiographical criteria regarding the sources of information.

PREDIFLOOD is the acronym of a Spanish research project. The general aim of the project is to improve the capacity of Predictivity of Flood events based on a large collection of historical information and modern data for all possible flood events in our study area. With these materials, hydraulic-hydrologic reconstructions and synoptic meteorological reconstructions will improve knowledge enough to produce tools for the improvement of preventive and early warning procedures for risk management situations.

Considering the topography and climatology of Catalonia, with a large number of ungauged basins, small dimension of basin but strong torrential rainfall events and high demographic concentration on the littoral as opposed to river mouths, improved knowledge for early warning procedures is strongly positive for management of these situations.

\section{Review of historical floods compilations in Spain}

\subsection{Early attempts at flood data collection (1850-1980)}

The first attempts to gather information on historical floods in Spain began in the second half of the 19th century, with the prevalence of positivism in historiography. These attempts took advantage of the network of historical archives created and managed by the public administration. However, these first works lack scientific objectives beyond the mere compilation of data. On the other hand, the period's context without technological resources, made the systematic collection and analysis of large quantity of historical information and data impossible. Consequently, most of these works do not have minimum conditions, and hence do not meet the minimum standards of historiographical rigour.

Nevertheless, some Spanish compilators took as a reference the work of the French historian Maurice Champion (Champion, 1858-1864). Of these, two local studies stand out: one in the town of Girona (Chía, 1861) and one in the town of Murcia (Hernández, 1885) - this last one including an analysis of the causes and effects of floods. A remarkable synthesis covering all the basins in the Iberian Peninsula was also published (Bentabol, 1900).

The first half of the 20th century saw a hiatus in flood compilations due to a movement of rejection of historiographical determinism. However, highly destructive floods which occurred in this period reignited the interest in this area of research and several local works of increasing methodological rigour appeared, such as those of the Turia River (Almela, 1957), the Ebro River (Blasco, 1959), the Segura River (Couchoud, 1965), the Llobregat River (Codina, 1971) and the junction of the Ter and the Onyar rivers at Girona (Alberch et al., 1982). At the same time, analytical studies began to appear, focused either on single events (Iglésies, 1971) or on the general characteristics of floods (López Gómez, 1983).

\subsection{The involvement of the administration (since 1980)}

In the last 30 years, the Spanish administration has made several attempts to gather historical floods information and to render it useful. More specifically, two types of organisms have led the way: basin authorities (called in Spanish "Confederaciones Hidrográficas") and civil protection authorities ("Dirección General de Protección Civil y Emergencias").

On the one hand, basin authorities early began to search and use information about historical floods as a complement of instrumental data, with the objective of better assessing floods' frequencies, flows, duration and behaviour. To this end, they launched several initiatives of historical floods data collection. Unfortunately, the personnel involved in those projects were civil engineers, with a poor background on historiographical methods; they looked for information in illorganized compilations of uneven quality, which did not permit a clear identification of the documentary sources. Furthermore, the information thus found was only used in comparing some extreme historical flood to those of the instrumental period and in creating flood chronologies that lacked any methodological criteria of exhaustiveness and, hence, had a mere informative objective. Besides all this, over the years, basin authorities have been placed under different ministries due to their diverse competencies on water (irrigation, drinkable water, waste water, infrastructures, taxes), and this hampered long-term projects, such as historical flood compilations.

The civil protection service is relatively new in Spain (Law 2/1985, 21 January 1985). This new concept of emergency prevention and management brings a new challenge to the collection and analysis of historical information. Indeed, this service needs great amounts of reliable information in order to perform the multidisciplinary analysis required both in emergency planning (prevention, rescue, evacuation, safe and vulnerable areas) and in urban planning.

Membership of the European Union also places new demands on the civil protection service. The Water Framework Directive (2000/60/EC of the European Parliament and of the Council, 23 October 2000) defined new work elements 
on water resources management and their severe manifestations, such as droughts and floods. But it was the EU Floods Directive (EU Floods Directive on the assessment and management of flood risks, 2007/60/EC of the European Parliament and of the Council, 26 November 2007), that, for the first time, specifically commanded EU State members to assess flood hazard and risk. In Spain, this task was already underway with the mapping of flooding areas; "Sistema Nacional de Cartografía de Zonas Inundables" (SNCZI, 2010).

Regarding historical floods, the transposition of the EU Floods Directive into Spanish legislation (Real Decreto 903/2010, 9 July 2010), in its articles 6 and 7, defined the use of historical information in flood risk assessment.

However, the results of the actions ordered by the EU Floods Directive are uneven in Spain. Instrumental information has been successfully catalogued and homogenized. But available historical information has not been thoroughly confirmed by systematic consultation of reliable documentary sources. Indeed, in relation to historical flood information, the work has been reduced to organizing and digitizing the data from the previous flood compilations done by the basin authorities (Catálogo Nacional de Inundaciones Históricas, 2006-2010). This is a mere accumulation of information, but not an improvement of its quality, quantity or applicability, because the source compilations are fragmentary and they lack both flood selection criteria and references to primary documentary sources.

Unfortunately, this has been the usual procedure in the treatment of historical floods information until now. Therefore, although powerful software programmes support these modern compilations, their applicability in flood analysis is very limited and they are seen as mere collections of anecdotes for informational pieces into calendars or yearbooks.

\subsection{Scientific approaches}

Apart from the efforts of administrations, there have also been scientific approaches to the collection of historical flood information in recent years, with the aim of creating flood compilations of European-homologable quality.

The first doctoral thesis on the subject was by Grimalt on the island of Mallorca (Grimalt, 1988), which was later published as a book (Grimalt, 1992). Since then, several research projects acquired historical information with specific criteria in order to produce consistent and reliable data series. However, these projects, which were costly and lasted from 2 to 4 years, were limited to a scarce number of chronologies in small areas - examples are the compilations of Maresme County (Barriendos and Pomés, 1993), of the Spanish Mediterranean coast (Barriendos and Martín-Vide, 1998) and of the basins of the Ter, Llobregat and Segre rivers (SPHERE Project, "Systematic, Palaeoflood and Historical data for the improvEment of flood Risk Estimation", EU Project EVG1-CT-1999-00010, 2000-2004). Also, the Geological Institute of Catalonia started a campaign of system- atic collection of information between 2008 and 2010 in order to map natural risks, but budget limitations stopped the survey and only the Pyrenees area section was completed.

These compilations done with scientific purposes, although scarce and modest, follow the methods of European research. This has allowed complex analyses such as: the improvement of climate behaviour estimations from multicentennial flood chronologies (Llasat et al., 2005; Barriendos and Rodrigo, 2006); the study of flash floods (Llasat et al., 2003; Barrera et al., 2006; Balasch et al., 2010a, 2011); or the reconstruction of the peak flows and the impacts of one of the worst floods in the Iberian Peninsula, that of November 1617 (Thorndycraft et al., 2006).

\section{Characteristics of the Prediflood database}

The Prediflood database contains information about historical floods that occurred in Catalonia (NE Iberian Peninsula) between AD 1035 and 2013.

The current state-of-the-art of historical floods in Spain (as previously described) and the potentialities of our contribution as outlined in this paper are very different. Previous official databases mostly took information only from a selected number of bibliographical references, but not defined by historiographical criteria or any specific order. The obtained database included a large amount of information, but with important weaknesses. On the other hand, previous research projects in this field have worked from documentary and bibliographical sources, but focused on very specific geographical sites.

We suggest and apply a systematic approach to bibliographical sources obtaining a complete identification of primary sources (historical documentary sources with full reliability: objectivity, eyewitness in real time, and so forth). A new online database and tools help a lot in this new approach and in the achievement of the research objectives.

Our research is focused in long flood chronologies for specific sites, but we also collect, integrate and analyse information from all existing flooded sites. This new approach changes the focus from "floods occurring in one location" to "all locations recording overflow during one flood event".

In our opinion, a flood event is so complex in atmospheric and surface processes that all possible information contributes to a better understanding of it.

Catalonia is a relatively mountainous region of $32114 \mathrm{~km}^{2}$ on the east Mediterranean coast of the Iberian Peninsula (Fig. 1). Due to both its location and its relief, it is prone to several flood-causing weather phenomena: severe thunderstorms, long frontal rain events, and massive snow thaw.

It is also a relatively populous area, and has recently undergone a period of massive construction, sometimes in floodprone areas, a consequence of a speculative building construction bubble. Therefore, exposure and vulnerability have increased in the last few decades. 


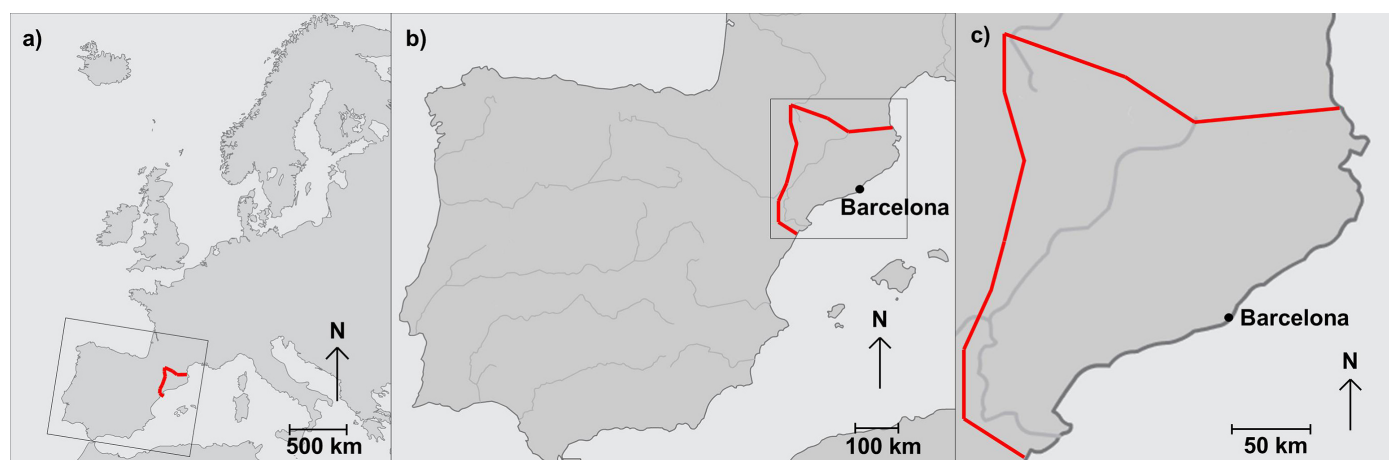

Figure 1. Location of Catalonia within Europe (a) and the Iberian Peninsula (b), and map of Catalonia (c). Own elaboration from a map by the National Geographic Society, Washington, DC, 2009.

\subsection{General criteria}

Due to the state of research in Spain, it is advisable to work with general criteria when managing historical flood information, in order to make it usable for future multidisciplinary studies.

\section{Considerations of the modern-day situation}

a. The bibliographical information on which modern databases are based is partial, obsolete, and not acquired with conventional historiographical criteria.

b. The search of historical documents with continuous, objective information of floods (local administration sources) has barely covered $3 \%$ of the total documents available in the National Documentary Heritage.

c. The use of primary documentary sources is rare. Thus, uncertainty about reliability and accuracy of data available is very high.

d. The databases have a closed design, with precise structures to organize information, adequate for instrumental data, but frustrating and not operative for historical information and its level of detail.

e. Closed-structure databases deem all their information certain, although research can bring many corrections, enlargements and even detection of serious errors, such as date or location of the flood, repeated flood records, or floods that never occurred.

As an example of working without a critical analysis of sources (historiographical procedures), one bibliographical reference with wrong information describes a flood in 1897 in Girona city caused by the overflow of the Guell River. If this reference is taken into account, we introduce wrong information into flood frequency analysis for this sector. Taking different documentary and bibliographical references in a cross-analysis, we concluded that this "flood" was in fact only a problem of rainfall infiltration on the roof of the City Hall.

\section{Proposed criteria (used in the "Prediflood" database)}

a. Open structure: with so many documentary and bibliographical sources not yet searched, designing fixedstructure databases is premature. The most operative alternative is having a collection of information entries in their original formats and, in parallel, a list or catalogue of these entries which can be used as a temporary database.

b. Positive error management: an open structure allows quick detection, correction and substitution of erroneous information. The creation of a new flood case in a database from not contrasted information must be avoided. New cases are generated from imprecise and doubtful information.

c. Traceability: every flood record should have a complete reference to a primary documentary source, from which the printed sources derive: monographs, articles, reports. A flood record is reliable only when its sources are completely traceable. In addition, this allows the maximum access to generated information.

Because of these previous factors and future needs, the information organization structure has two different parts. On the one hand, all the found materials in documentary and bibliographical sources are stored in their original formats. The minimal transformation and reduction permits the use of the information in successive improvements and corrections that would arise after new material gathering. On the other hand, a spreadsheet records the basic information required for all kinds of queries, at the same time allowing quick changes in the created categories and items.

To this end, the Prediflood database information is organized into three areas:

Area 1: Digital Archive. Most of the information already available in official/public databases is contained in digital 
archives supported by different software, from complex files developed by specific DB software (i.e. Access) to simple scanned materials in pdf format. All these materials are considered "Digital Archive". We also include digital files of publications, technical reports, academic works, as well as instrumental data.

Area 2: Factual Archive. This refers to materials in different physical formats - materials preserved in historical archives, such as old photographs, pictures, painting, cartography; we also include epigraphic flood marks (old buildings, bridges, etc.). In the best case, we can find direct testimonies of oral history preserved on old cassette tapes, etc.

Area 3: Textual Archive. This is the core of our research work. We have "reset" the information available in different databases into text format (Word files) for a better management of such a large and complete amount of information. We are exploring new bibliographical and documentary sources. New information must be added with detailed insertions case-by-case, date-by-date. All this work is made in descriptive texts (of course, including numeric and instrumental data).

\subsection{Location and codification system}

The Prediflood project's research area is the Catalonia administrative unit, which is divided into two group of basins: (1) final part of Ebro River basin (including Segre River basin, a tributary of the Ebro), (2) "Catalan Interior Basins", all rivers which flow directly into the Mediterranean between Ebro River and french frontier.

The period studied is the last 500 years, which is the usual length that the law requires to define flooding areas under extreme magnitude events. Nevertheless, strict time limits are inadvisable in historiographical research. Historical events information is not always complete and detailed but sometimes has cross-references to previous events and, therefore, an extension of the studied period contributes to an improvement of the initial information.

As an example of the process of collecting all possible references, consider Event 1380, March 7th. Onyar River, Girona city (Level 5, Catastrophic).

- Chía (1861) mentions this flood as flowing by Argenteria Street, damaging two monasteries, destroying a city gate and causing three deaths.

This report is based on a section of correspondence from the City Council Archive of Girona, volume of year 1380 .

- Marqués (1979a, b) describes this flood as having a measurement of eight spans of flooding level on "Força" Gate $(1,56 \mathrm{~m})$ and the destruction of the other gate of the city.

This source does not mention primary (documentary) sources.
- Alberch et al. (1982) describes a partial collapse of the city wall, affecting one building in Argenteria Street (with three dead).

This source is based on the City Council Minute Books, of year 1381, preserved in the City Council Archive of Girona.

The information has been singularized to the locations where a flood is described or documented. For the geographical location, the ACA (Catalan Water Agency) procedure has been used:

1. Basin

2. River

3. Town

\section{Element}

A full identification up to level 3 is the most usual, using the official name of municipalities, the basic local administrative unit in Spain. The use of smaller units has not been envisaged due to the great diversity of the descriptive level of the different flood records. It is preferable to keep this information in a raw state for eventual specific analyses when needed. All details are preserved with original names and descriptions. Most of them will have to be cross-checked with new data sources, if the work proceeds, in the near future.

Time location is not excessively complex. The consulted documentation is usually precise with dating. Fortunately, we focus on administrative documentary sources and local newspapers. Dating of this type of document is exact. Only calendar adjustments are required (i.e. Julian to Gregorian calendar style). Curiously, the worst indeterminations are found in bibliographical sources; this justifies the effort to reach original documentary sources for the historical period events. In contrast, the local press provides rich information, even allowing hour resolutions, very useful in hydrological and meteorological reconstructions.

The only issue that deserves attention is the possibility of recording the duration of some events. In larger rivers, the precise dating of the beginning of floods and of their peak flows can be very helpful.

Dates are the key element proposed to identify every flood record, because of their high reliability. Every record will have a code composed of the complete date (YYYYMMDD) and an order number. When only one record is available for a flood event, this order number is " 01 ". When different flood cases have the same date, order number simply shows the order in which records have entered the database.

After this identification of "Case Code", when a group of records are suspected, according to hydrological or meteorological evidence, to correspond to the same event, an independent code for the event is also generated (YYYY-MM). For different flood events in the same month, we distinguish with successive letters $(\mathrm{a}, \mathrm{b}, \mathrm{c}, \ldots)$. After this provisional 
Table 1. Example of flood case and flood event codification.

\begin{tabular}{llllllll}
\hline Location & River & Year & Month & Day & Order & Case code & Event code \\
\hline Flix & Ebro & 1787 & October & 8 & 3rd & 1787100803 & $1787-10$ \\
Xerta & Ebro & 1787 & October & 8 & 4 th & 1787100804 & $1787-10$ \\
Tortosa & Ebro & 1787 & October & 9 & 1 st & 1787100901 & $1787-10$ \\
\hline
\end{tabular}

coding, when the gathering of quantitative information is sufficient, a definitive procedure for coding should be applied, considering duration, extension, severity of flood event (see Table 1).

\subsection{Classification system by assessment of impacts}

The collected floods require a minimal common characterization in order to be classified. Most of the flood records are still to be completed with more precise and reliable information search, but, for the moment, the most evident traits can be used. The more common elements to an event of any time are those referring to its basic hydrological behaviour and the impacts it caused. The combination of these two criteria has been used in many studies at a European level. In the case of Spain, the first proposal had three levels of classification (Barriendos and Pomés, 1993; Barriendos and Martin-Vide, 1998; Llasat et al., 2005):

1. Non-overbank flood + disturbance: ordinary flood

2. Overbank flood + disturbance + damage: extraordinary flood

3. Overbank flood + damage + destruction: catastrophic flood

The analysis of many and very diverse floods during project SPHERE led to a refining of the classification system, hereby presented with the latest improvements:

ERR Erroneous information: The flood never existed

0. Unnoticeable flood, no damage: No flood

1. Non-overbank flood + disturbance: Ordinary flood

2. Non-overbank flood + disturbance + damage: Ordinary/extraordinary flood

3. Overbank flood + disturbance: Extraordinary flood

4. Overbank flood + disturbance + damage: Extraordinary/catastrophic flood

5. Overbank flood + damage + destruction: Catastrophic flood

In general, the basic criteria are the occurrence of flood and whether it is an overbank flood or not. Then, there are two further levels: first, the capacity to damage nonpermanent elements (vehicles, cattle, stored goods) or light structures (catwalks or temporary wooden structures), and second, the capacity to destroy completely or partially permanent structural elements, either in an urban or in a rural environment: stone bridges, walls and other defensive elements, watermills, buildings, irrigation systems, or roads and railroads. Regarding agriculture, a flood is considered destructive if it has rooted out large fields, or if it has destroyed the harvest or the productive plants (grapevines, fruit trees), removing the productive soil and leaving large fluvial deposits of any kind - in summary, catastrophic situations that will need important economic resources and several years for a full recovery, or that mean the abandonment of the affected elements.

The classification system does not take into account human fatalities due to the occurrence of this kind of impact being random in relation with the severity of the flood. Regarding human victims, a lot of interesting considerations could be described and analysed. In historical time, the numbers of victims are very low. We suggest that high vulnerability provoked an automatic mechanism of reduction of exposure. However, since the Industrial Revolution, people vulnerability has been greatly reduced by new technical resources. But then exposure increased and fatalities increased. People's poor prior assessment of risk is also an important factor for explaining victims in flood events in the area under study.

Consequently, we considered first that human impacts (displaced, injured, dead victims) are related to inhomogeneous and hazardous factors. They cannot be applied to an initial general flood event analysis. In a second stage of the research, we will introduce vulnerability indices, in the hope that this information will be useful to improve flood event knowledge.

To fix the evaluation of impacts on permanent structural elements is a more objective approach and adequate for this task. The effects on population are recorded but only used in specific studies.

A last issue to take into account is the lack of a criterion of severity classification according to the number of affected catchments. Due to the characteristics of the Mediterranean regions, with intense torrential but not always extensive rainstorms, and with a complex orography, this territorial affection criterion would not be very representative of the magnitude of the floods. Nevertheless, the accumulation 
of information will lead to the application of such a criterion in the near future, which will be useful in identifying and classifying large floods.

Firstly, we focus on a physical/natural event. To reduce bias produced by human presence changing with time (new structural elements, population growing, new land uses), we focus the research on two basic criteria (overflowing and impacts) on the same sites when possible. For example, we generate different levels of classification fixing one group of streets, one bridge or dike (unchanged in time), and observing when these elements are overflooded, when they are damaged and when they are destroyed, but always taking into account the same elements, whenever possible. When local changes of bed river are very important or large hydraulic infrastructures are built upstream, we finish flood chronologies on this site.

In a next step to be developed in future research, we want to maintain physical event considerations, but introduce human aspects. We want to collect urbanistic and demographic information by municipalities (demographic evolution, quantity and type of buildings) to generate vulnerability indices (of course, considering evolution in time). An improved flood-event classification will be developed considering this information applied in different temporal frames, adjusted to singularities of every municipality. We recognize that this new generation of data analysis is in a preliminary stage. We will need a few years to have it for all Spanish Mediterranean basins.

\subsection{Meteorological and hydrological information}

Historical accounts usually have complete information about time and space location of the flood and the most relevant damage. This detailed information is available because of the use of administrative sources of local authorities. The main objective of these documents is to record exact and detailed description of impacts and causes, in order to define and apply a programme of reconstruction of public infrastructure. However, information on meteorological and hydrological issues is scarcer, only being frequent in the most recent accounts. Because of that, it is convenient to identify and singularize the information that can be of special interest in the reconstruction of those issues.

The database has cells to confirm the presence of meteorological information - duration and behaviour of the precipitation, previous rain events (or any other described variable, such as pressure or wind speed and direction and associated phenomena). Regarding the hydrological behaviour, the data to be taken into account are: maximum water height, flood behaviour and other hydrological information such as changes in the channel, sediment accumulation, landslides.

\section{Firsts results of the "Prediflood" database}

The results of the first compilation of flood material (June 2013-March 2014) are very positive. But it would be a mistake to consider this as the final step of the process. Regrouping already known information is not a research objective in itself. It is just the initial phase of an open-ended process, which must lead to the maximum gathering of information about an unsuspectedly high number of events that have been detected.

The work will be gradual and it will go beyond the initial Prediflood project itself - this is the only way to acquire historical flood information that is truly useful for the meteorological and hydrological reconstruction of severe events. Thus, the results presented here are a mere starting point, and they remain open to future campaigns of improvement and applied research.

As of April 2014, the "Prediflood" database has the following structure and content:

- 2711 flood cases (flood records) in Catalonia, organized in 1103 flood events;

- Period effectively covered: AD 1035-2013;

- Accumulation of textual materials: 1246 pages;

- Accumulated material from other basins in the Iberian Peninsula, with no exhaustiveness:

- Peninsular basins: 873 flood cases,

- Insular basins (Balearic Islands): 111 flood cases,

- Basins in Roussillon (SE France): 250 flood cases,

- Total absolute: 3945 flood cases.

The distribution in time of the flood cases and events (Fig. 2a and b) shows a logical concentration in the last 200 years, as a result of the greater availability of information, but also due to the increase in exposure and vulnerability in the face of risk as a result of population growth, the industrialization of river areas in the 19th century, and the intensive urban development along the coast during the second half of the 20th century.

For this reason, data analysis in later works will consider internal periodization - every basin has its specific historical context evolution, but general periods could be:

- Years ca. 1000-1500: information poorly detailed and scattered. Population in small location with low exposition to flood events.

- Ca. 1500-1750: qualitative detailed and homogeneous information. Stable locations with important level of exposition to flood events.

- Ca. 1750-1850: highest level of qualitative information. First quantitative data available (meteorological, 

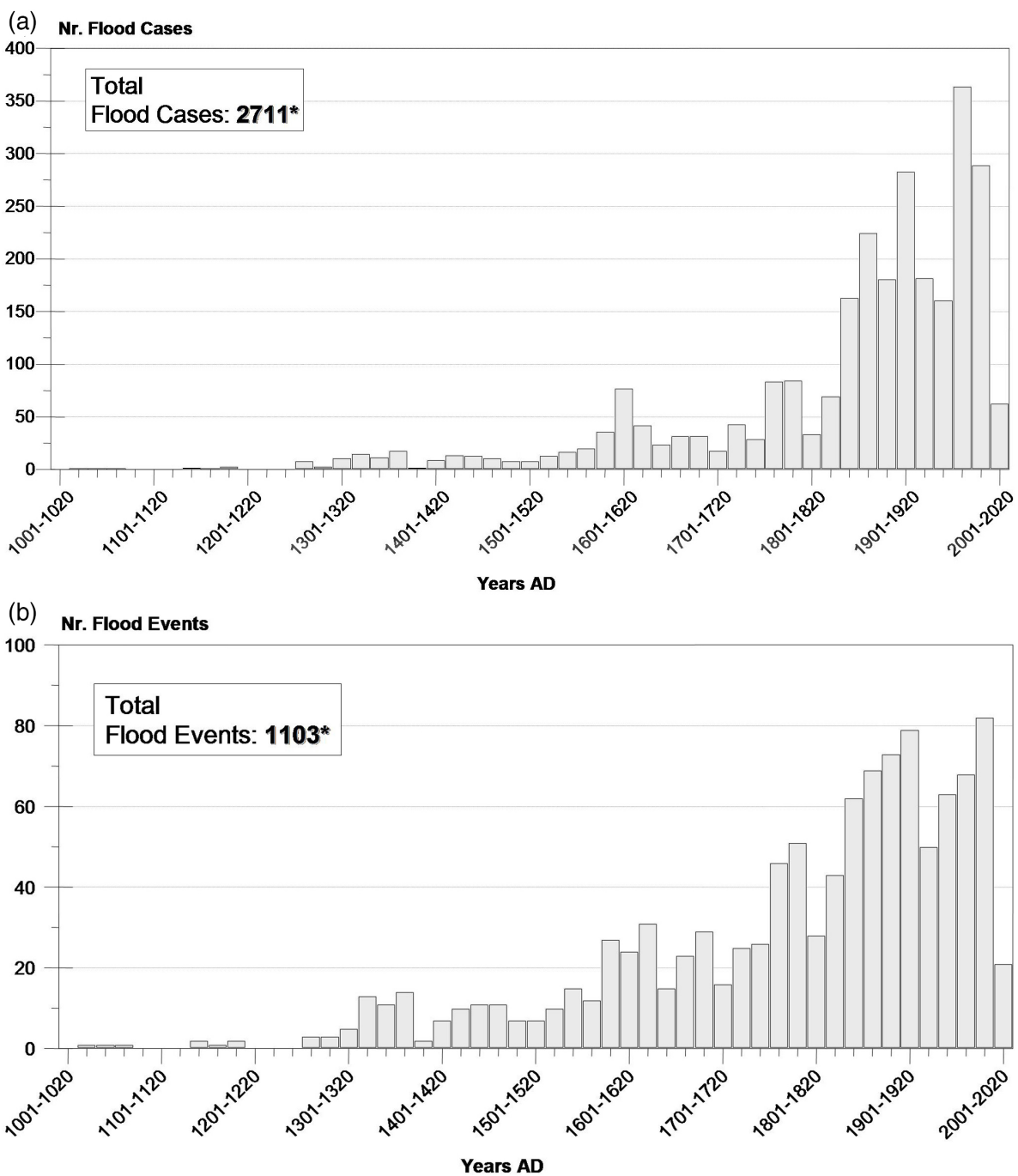

Figure 2. Bidecadal distribution of flood cases (a) and flood events (b) of the Prediflood database information (own elaboration). ${ }^{*}$ Three flood cases/events fall outside of the period AD 1035-2013.

demographic statistics, tributary reports). Strong demographic growth producing an important increase of vulnerability.

- Since ca. 1850: quantitative information is available and qualitative primary information is diversified (administrative sources, local newspapers, technical reports). Locations increase exposure but also different preventive structural works reduce vulnerability. Case-by-case analysis is required.

The number of flood cases in relation to the identifiable events reveals some interesting matters:

- one case per event: 756 flood events,

- between one and ten cases per event: 306 flood events,

- 10 or more cases per event: 41 flood events.
The great number of events with only one documented flood case highlights the typical regime of torrential precipitation, very intense but not large, which causes serious but localized overbank floods. But it also highlights the insufficient historiographical research that has not more completely defined flood events. A single-cased flood event is a stimulus to deepen the research into that area and date.

The greatest events, with 10 or more documented cases, are optimal starting points to deepen the research. They occurred in a relatively recent period, thus their study will be more efficient. Besides, their already proved severity can be definitely characterized and brings more information for the meteorological and hydrological reconstruction. A detailed study of these high-impact events is an immediate usage of the Prediflood database (see Tables 2 and 3).

Finally, the results of the "Prediflood" database can be compared to those of the compilations of the competent 
Table 2. Relation of flood events selected according to severity (10 or more cases per event). Chronologically sorted.

\begin{tabular}{|c|c|c|c|}
\hline $\begin{array}{l}\text { Nr. } \\
\text { order }\end{array}$ & Year & Extreme dates & $\begin{array}{l}\mathrm{Nr} . \\
\text { cases }\end{array}$ \\
\hline 1 & 1617 & 30 Oct -6 Nov & 47 \\
\hline 2 & 1787 & 25 Sep-9 Oct & 13 \\
\hline 3 & 1842 & $23-26$ Aug & 29 \\
\hline 4 & 1850 & $15-21 \mathrm{Sep}$ & 26 \\
\hline 5 & 1853 & 23-26 May & 19 \\
\hline 6 & 1856 & $8-16$ Jun & 11 \\
\hline 7 & 1863 & $7-8$ Oct & 12 \\
\hline 8 & 1866 & 19-25 Oct & 10 \\
\hline 9 & 1874 & 22-23 Sep & 69 \\
\hline 10 & 1890 & 18-19 Sep & 15 \\
\hline 11 & 1898 & 15-18 Jan & 25 \\
\hline 12 & 1901 & $21 \mathrm{Sep}$ & 13 \\
\hline 13 & 1907 & $10-16$ Oct & 30 \\
\hline 14 & 1907 & $21-25$ Oct & 89 \\
\hline 15 & 1913 & 29-30 Sep & 16 \\
\hline 16 & 1919 & 6-9 Oct & 13 \\
\hline 17 & 1921 & 16-18 Aug & 17 \\
\hline 18 & 1926 & 31 Aug-4 Sep & 16 \\
\hline 19 & 1932 & $11-17$ Oct & 11 \\
\hline 20 & 1937 & $25-28$ Oct & 43 \\
\hline 21 & 1940 & 16-18 Oct & 21 \\
\hline 22 & 1942 & 27-28 Apr & 12 \\
\hline 23 & 1943 & $15 \mathrm{Dec}$ & 21 \\
\hline 24 & 1944 & 24-25 Feb & 12 \\
\hline 25 & 1951 & $2-12$ Oct & 13 \\
\hline 26 & 1962 & 24-26 Sep & 26 \\
\hline 27 & 1962 & 10-17 Oct & 19 \\
\hline 28 & 1962 & $4 \mathrm{Nov}$ & 17 \\
\hline 29 & 1963 & 3 Aug & 11 \\
\hline 30 & 1963 & 11-14 Sep & 11 \\
\hline 31 & 1965 & 4-9 Oct & 12 \\
\hline 32 & 1969 & 3-5 Apr & 17 \\
\hline 33 & 1970 & $10-12$ Oct & 31 \\
\hline 34 & 1971 & 20-21 Sep & 26 \\
\hline 35 & 1973 & 7-8 Sep & 11 \\
\hline 36 & 1977 & 18 Oct & 17 \\
\hline 37 & 1982 & $15-16 \mathrm{Feb}$ & 17 \\
\hline 38 & 1982 & 6-8 Nov & 38 \\
\hline 39 & 1984 & 29 Sep & 11 \\
\hline 40 & 1987 & $3-10$ Oct & 16 \\
\hline 41 & 1994 & $10-11$ Oct & 29 \\
\hline
\end{tabular}

institutions: basin authorities and civil protection service (see Table 4).

The available databases, organized in hydrographical basins, have uneven time coverage. In some cases, importance has been attached to very ancient events, whereas other basin authorities have preferred to focus their study in a more realistic period, of about 500 years long, to be used in the 500-year return period calculations required in different land planning instruments. However, these databases contain few
Table 3. Relation of flood events selected according to severity (10 or more cases per event). Sorted by number of documented cases.

\begin{tabular}{|c|c|c|c|}
\hline $\begin{array}{l}\text { Nr. } \\
\text { order }\end{array}$ & Year & Extreme dates & $\begin{array}{l}\mathrm{Nr} \text {. } \\
\text { cases }\end{array}$ \\
\hline 14 & 1907 & $21-25$ Oct & 89 \\
\hline 9 & 1874 & 22-23 Sep & 69 \\
\hline 1 & 1617 & 30 Oct -6 Nov & 47 \\
\hline 20 & 1937 & $25-28 \mathrm{Oct}$ & 43 \\
\hline 38 & 1982 & 6-8 Nov & 38 \\
\hline 33 & 1970 & $10-12$ Oct & 31 \\
\hline 13 & 1907 & $10-16$ Oct & 30 \\
\hline 3 & 1842 & 23-26 Aug & 29 \\
\hline 41 & 1994 & $10-11$ Oct & 29 \\
\hline 4 & 1850 & 15-21 Sep & 26 \\
\hline 26 & 1962 & 24-26 Sep & 26 \\
\hline 34 & 1971 & 20-21 Sep & 26 \\
\hline 11 & 1898 & 15-18 Jan & 25 \\
\hline 21 & 1940 & 16-18 Oct & 21 \\
\hline 23 & 1943 & $15 \mathrm{Dec}$ & 21 \\
\hline 5 & 1853 & 23-26 May & 19 \\
\hline 27 & 1962 & 10-17 Oct & 19 \\
\hline 17 & 1921 & 16-18 Aug & 17 \\
\hline 28 & 1962 & $4 \mathrm{Nov}$ & 17 \\
\hline 32 & 1969 & 3-5 Apr & 17 \\
\hline 36 & 1977 & $18 \mathrm{Oct}$ & 17 \\
\hline 37 & 1982 & $15-16$ Feb & 17 \\
\hline 15 & 1913 & 29-30 Sep & 16 \\
\hline 18 & 1921 & 31 Aug-4 Sep & 16 \\
\hline 40 & 1987 & $3-10$ Oct & 16 \\
\hline 10 & 1890 & 18-19 Sep & 15 \\
\hline 2 & 1787 & $25 \mathrm{Sep}-9$ Oct & 13 \\
\hline 12 & 1901 & $21 \mathrm{Sep}$ & 13 \\
\hline 16 & 1919 & 6-9 Oct & 13 \\
\hline 25 & 1951 & $2-12 \mathrm{Oct}$ & 13 \\
\hline 7 & 1863 & 7-8 Oct & 12 \\
\hline 22 & 1942 & 27-28 Apr & 12 \\
\hline 24 & 1944 & 24-25 Feb & 12 \\
\hline 31 & 1965 & 4-9 Oct & 12 \\
\hline 6 & 1856 & 8-16 Jun & 11 \\
\hline 19 & 1932 & 11-17 Dec & 11 \\
\hline 29 & 1963 & 3 Aug & 11 \\
\hline 30 & 1963 & 11-14 Sep & 11 \\
\hline 35 & 1973 & 7-8 Sep & 11 \\
\hline 39 & 1984 & $29 \mathrm{Sep}$ & 11 \\
\hline 8 & 1866 & $19-25$ Oct & 10 \\
\hline
\end{tabular}

events: between 150 and 250 events per basin. The Ebro and the Guadalquivir basins stand out with about 500 events, a number very much due to their large areas. Catalonia, with an average area compared to other basins, reaches 1103 flood events.

The use of an objective criterion to compare the general results in Spain with those of the Prediflood project in Catalonia (Gaume et al., 2009) show a space and time coverage obviously greater for the whole of Spain 
Table 4. Comparative values between the flood compilations of Civil Protection Spain and the Prediflood project. Source: "Catálogo Nacional de Inundaciones Históricas" (2006-2010), Ministerio del Interior, España.

\begin{tabular}{lrcrrrr}
\hline Basin & $\begin{array}{r}\text { Area } \\
\left(\mathrm{km}^{2}\right)\end{array}$ & Period & $\begin{array}{r}\text { Nr. } \\
\text { Events }\end{array}$ & Years & Coverage $^{\mathrm{a}}$ & Density $^{\mathrm{b}}$ \\
\hline Duero & 78954 & $1483-1985$ & 278 & 503 & 39.7 & 7.0 \\
Segura & 18869 & $1482-1982$ & 214 & 501 & 9.5 & 22.5 \\
Júcar & 42989 & $1088-1983$ & 217 & 896 & 38.5 & 5.6 \\
Tajo & 55645 & $849-1979$ & 159 & 1131 & 62.9 & 2.5 \\
Ebro & 85399 & BC49-1984 & 554 & 2034 & 173.7 & 3.2 \\
Guadalquivir & 63972 & $1483-1985$ & 474 & 503 & 32.2 & 14.7 \\
Norte + Galicia & 40894 & $1482-1983$ & 141 & 502 & 20.5 & 6.9 \\
Guadiana & 59677 & $620-1985$ & 149 & 1366 & 81.5 & 1.8 \\
Sur & 17969 & $1544-1983$ & 162 & 440 & 7.9 & 20.5 \\
Pirineo Oriental & 16418 & $1483-1983$ & 162 & 501 & 8.2 & 19.8 \\
\hline Total Spain & 493838 & & 2579 & $838($ av. $)$ & 413.8 & 6.2 \\
Prediflood & 32114 & $1035-2013$ & 1103 & 979 & 31.4 & 35.1 \\
\hline
\end{tabular}

${ }^{\text {a }}$ Coverage: (years $\times$ surface) $/ 10^{6} \mathrm{~km}^{2}$ (according to Gaume et al., 2009); ${ }^{\mathrm{b}}$ Density: Nr. Events / coverage (according to Gaume et al., 2009); ${ }^{\mathrm{c}}$ Pirineo Oriental Basin: data provided directly by Catalan Water Agency (ACA)

compared to Catalonia (413.8 yr $\times$ surface $/ 10^{6} \mathrm{~km}^{2}$ and $31.4 \mathrm{yr} \times$ surface $/ 10^{6} \mathrm{~km}^{2}$, respectively). However, considering the number of events in Spain (2579 events) and Catalonia (1103 events), the density of events in relation to their space and time coverage reaches a value of 6.2 events/coverage in Spain and 35.1 events/coverage in Catalonia, which is almost six times greater.

\section{Historiographic data collection procedures}

\subsection{Justification for a historiographical research}

Historical floods information has specific sources, documentary and bibliographical, the traditional area of research of historians. However, natural events are not, in general, appealing to this collective. Floods simply appear as mere anecdotes in local historiography, and only deserved some systematic effort during the positivist period.

The present context of natural risks in their interaction with human activities makes this research field interesting. In a few years, historical climatology has shown its development capacity in the scientific literature from information exclusively collected in historical documentary sources on the issue of floods (among others: Camuffo and Enzi, 1996; Glaser, 1996; Pfister, 1998; Brázdil et al., 1999, 2006; Wetter et al., 2011).

The situation in Spain is optimal to this kind of research thanks to the great documentary heritage preserved. However, historiographical research has focused on political and social issues. Up to the present, only $3 \%$ of the documentary sources of specific interest to floods have been explored. (In Catalonia, this percentage is approximately $5 \%$ ). Local his-

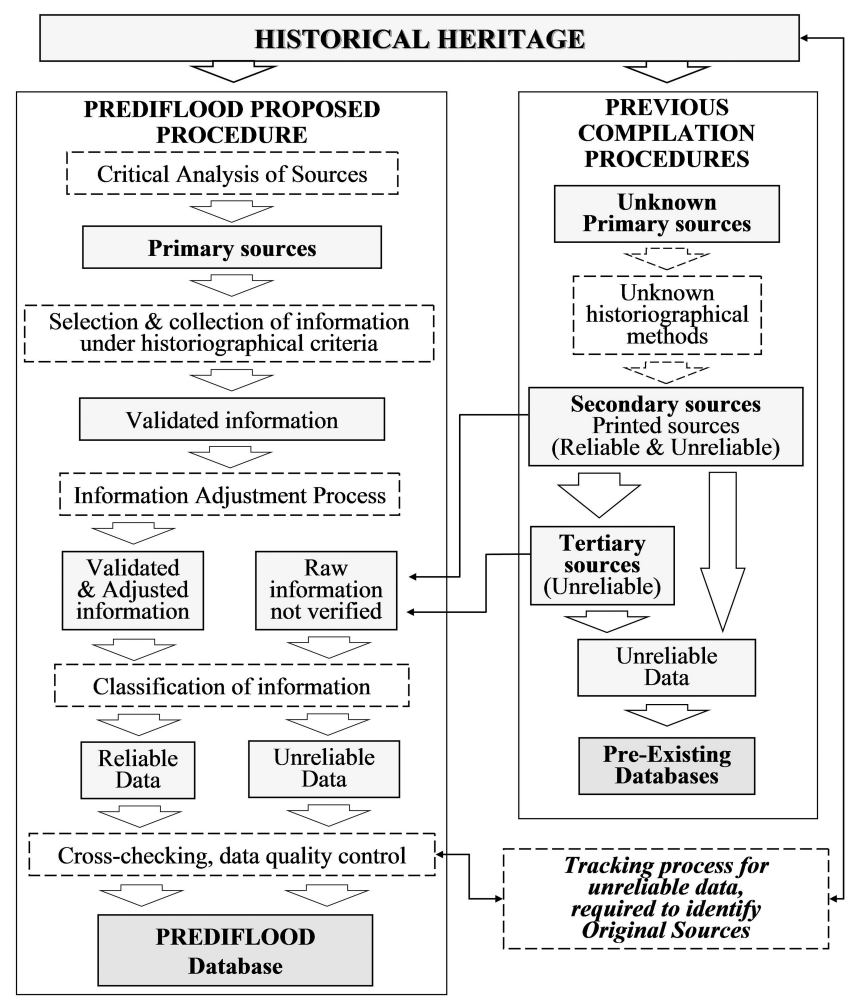

Figure 3. Overview of the methodological procedure of historical floods data collection (own elaboration).

toriography has accessed a greater number of documentary sources, but only to generate lists of flood dates.

The administrations charged with managing basins and emergency situations have used these bibliographical sources but the results have been scarce and limited despite the 
potentiality of the available documentation. The solution to this situation can come from historiographical research itself, and the results can be as positive as those of previous European experiences.

The majority of flood events in Spain are based on an insufficient exploitation of historiographical sources. Reaching a complete identification of these sources is, by itself, a study with multiple positive aspects (see Fig. 3).

\subsection{Proposal of classification of information sources}

The development of a study on so large and diverse a range of historical sources requires a good classification of them. The following proposal is based on their reliability levels and content format:

\section{Primary sources}

Information for flood events generated by contemporary eyewitness authors

a. Documentary sources ${ }^{1}$

b. Local newspapers ${ }^{2}$

2. Secondary sources

Information obtained from primary sources by not eyewitness authors

a. Scientific literature ${ }^{1}$

b. Historiographical sources and thematic works ${ }^{2}$

3. Tertiary sources Information obtained from secondary sources by not eyewitness authors

a. Technical reports ${ }^{1}$

b. Non-specialized works and social networks collections $^{2}$

Q. Quantitative data

Information recorded in numeric or quantifiable formats (All sources can contain quantitative data, generated by themselves or copied and transmitted)

a. Instrumental sources

b. Paleolimnimetry: epigraphic and textual flood marks

The source levels relate to their proximity to the events. Every source level has some objective sources, with which data gathering is almost complete, and some subjective ones, which offer incomplete information.

\footnotetext{
${ }^{1}$ Objective sources, quasi-complete data series
}

${ }^{2}$ Subjective sources, uncomplete data series

\subsection{Proposed procedures}

The first analysis of the compiled floods shows the levels of the sources of information. Data exploitation can be immediate, but the classification of sources can highlight the reliability and quality of the sources used and, therefore, of the available information. If required, the origin of the information can be investigated until arriving at the primary level sources.

Given the present state of references on flood cases, the research effort should focus on finding the primary sources for most of them ensuring, at least, one reliable and objective source of information. Application of this principle of traceability would have a number of positive aspects:

1. The starting point would be already available information, thus not limiting its availability but consolidating and improving its reliability.

2. By reaching primary sources of a public administrative nature, information endorsed by a public notary would become available. The maximum reliability provided by such testimony would strengthen reconstruction studies based on the information contained in these sources.

3. New bibliographical and documentary sources would be brought to light. This would enlarge the available information and new floods cases and events would be detected subsequently, in a sort of chain reaction.

4. A line of research would be defined for historians. In the case of Spain, it would doubtlessly mean many years of work. The possibility would arise to expand the research into poorly explored areas or to deepen it into events that deserve a more detailed study.

5. The accumulation of the maximum available description of impacts and quantifiable information about hydrological and meteorological information, up to an acceptable degree of exhaustiveness, would be reached. It would not be all the desirable information but, at least, all information known to date.

6. Such studies, besides detecting unknown flood information, could also detect information about other infrequent natural risks (earthquakes, landslides and rare meteorological phenomena).

\section{Reconstruction methodology}

Our multidisciplinary reconstruction of historical floods consists of three parts:

1. hydraulic reconstruction, the objective of which is the calculation of the peak flow (or, when possible, the whole hydrograph) of the flood, 


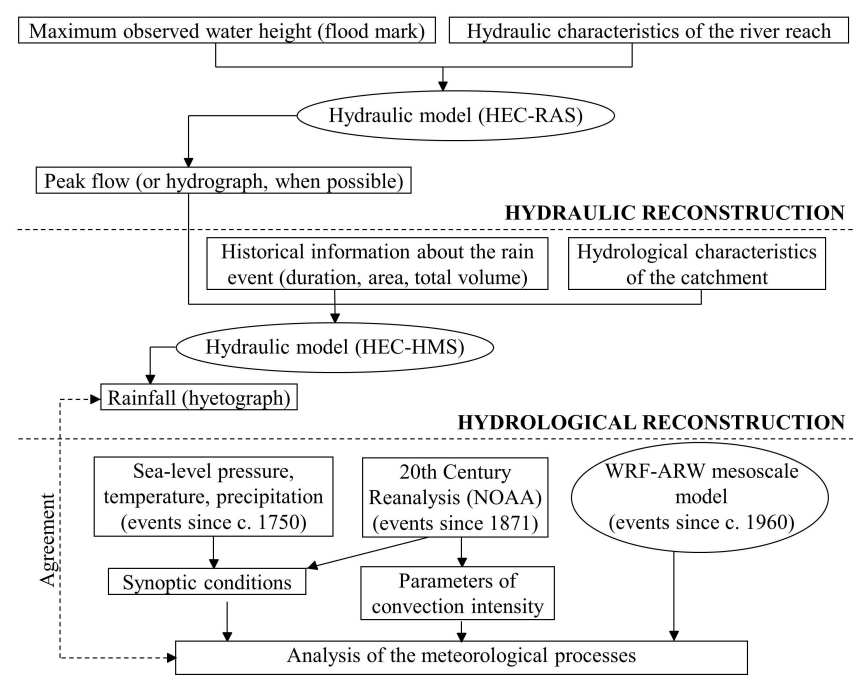

METEOROLOGICAL RECONSTRUCTION

Figure 4. Overview of the multidisciplinary reconstruction methodology of historical floods (own elaboration).

2. hydrological reconstruction, the objective of which is the calculation of the hyetograph of the rain event that caused the flood,

3. meteorological reconstruction, the objective of which is to analyse the meteorological processes before and during the rain event that caused the flood.

These three parts are linked - the results of the hydraulic reconstruction (flood's peak flow or hydrograph) are needed in the hydrological one, and the results of the hydrological reconstruction (hyetograph) should agree with the results of the meteorological one (Fig. 4).

The three reconstructions occur in very different spatial scales: typically, the hydraulic reconstruction takes place along a river reach (of area up to a dozen kilometres squared); whereas the hydrological one takes into account the whole catchment (from some dozens to thousands of kilometres squared; and the meteorological reconstruction is done, depending on the meteorological phenomenon causing the event, from a local (hundreds of kilometres squared) to a regional scale $\left(1\right.$ million $\left.\mathrm{km}^{2}\right)$. Whatever the case, all of them need historical information in order to feed the models used with the required input data and initial and boundary conditions.

\subsection{Hydraulic reconstruction}

The objective of the hydraulic reconstruction is to calculate the flood's peak flow from the maximum water height observed or flood mark, recorded on a plaque or in a written document.

This calculation can be quickly done (although with a high uncertainty) with Manning's empirical equation, which relates, in one section of the stream, the flow of water to the ge- ometrical and friction characteristics of the section, summarized in only four values: the section's area and wet perimeter, the longitudinal slope and a roughness coefficient.

However, the precision of a peak flow calculation is improved with the use of hydraulic models. Typically, these models use physically based equations (e.g. Bernouilli, onedimensional Saint Venant) in dozens of sections along a reach of river several hundreds metres long. The major drawback is that they need more input data.

Simple hydraulic models (e.g. WSPRO, QUICK-2, CAUCES) can only operate in steady flow conditions (that is, no variation in time is allowed: they calculate the situation of a still instant), while others (e.g. HEC-RAS, DAMBRK, SWMM, Mike $11 \mathrm{HD}$ ) can calculate in unsteady flow conditions, thus obtaining more accurate results, especially in river reaches with floodplains with a great water-storing capacity.

Similarly, some simpler models do their calculations in one dimension only (all flow lines are perpendicular to the cross-section), while more sophisticated and accurate ones (e.g. Iber, Sobek, Mike 21 and FLO-2D) do them in two dimensions (flow lines can be oblique to the cross-section). The difference in accuracy between 1-D and 2-D models increases in winding stretches, in those in which the water velocities in the channel and on the floodplain are very different, and in those where the flow is clearly not unidirectional.

However, the gain in accuracy with the use of unsteady flow conditions or 2-D models comes at a higher effort in input data acquisition and, especially, in computation time, which can even make the use of complex models impractical in historical floods reconstruction, because they have to be applied iteratively. Besides, a high standard of accuracy in the calculations is not essential in reconstructing historical flows, because the input data have themselves a high degree of uncertainty. Because of this, and for the sake of homogeneity between data-rich and data-poor sites, we systematically use the 1-D hydraulic model HEC-RAS in steady flow conditions (USACE, 2008), which gives accurate enough results (Balasch et al., 2010a, 2011). Nevertheless, we also apply the 2-D model of Iber (Iber 2010; Ruiz-Villanueva et al., 2013) in some cases which would otherwise produce excessive inaccuracy: highly urbanized or very sinuous reaches or with large floodplains.

It must be noted that models calculate hydraulic parameters (water velocities and depths) from a given peak flow, whereas we need the opposite: to calculate the peak flow from a given water height. Thus, the hydraulic model has to be applied iteratively, feeding it with tentative peak flows until the observed water height is approached (Fig. 5).

The input data that the model needs, besides the tentative peak flow, are the stretch's geometry and friction against water flow, the former given by the digital elevation model, and the latter given by Gauckler-Manning roughness coefficients, found in tables that relate friction with type of surface, sinuosity, vegetation, obstacles and cross-section contractions or expansions (Chow, 1959). Also, a hydraulic model 


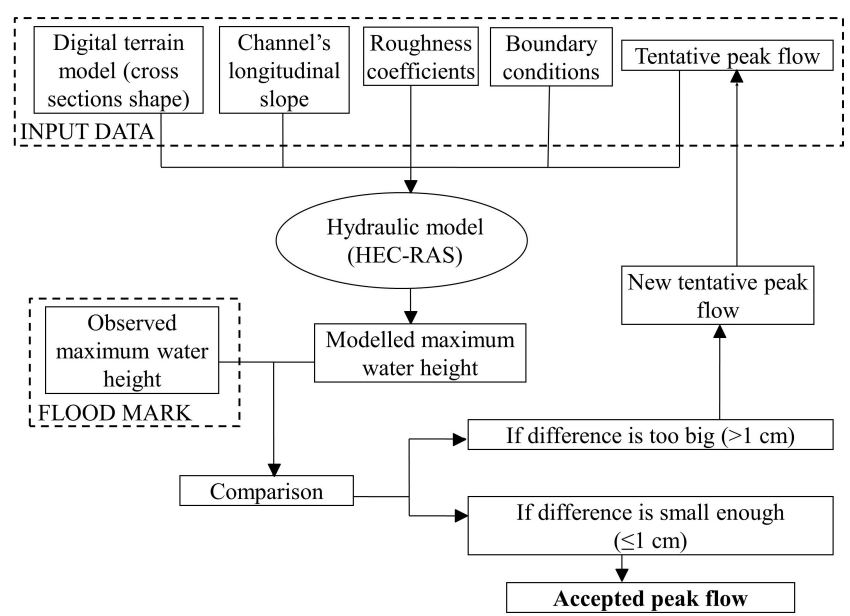

Figure 5. Iterative procedure used in the hydraulic reconstruction of peak flows (modified from Balasch et al., 2010b).

has to be given boundary conditions, which link what happens inside the modelled river reach with what happens upstream and downstream.

All these input data have to be adequately adapted to be as close as possible to their values at the time when the historical flood to be reconstructed took place. Therefore, old maps and documents are essential in reconstructing the channel and floodplain morphology at the time of the flood (obstacles, meanders, islands) and in hypothesizing the roughness coefficients. It must be noted that since they are acquired by estimating and hypothesizing from old documents, the input data have a high degree of uncertainty. Again, this process adds a high degree of uncertainty to the input data.

In those rare cases where measured flow data are available, they should be used in calibrating the hydraulic model in that reach, that is, in estimating more accurately roughness coefficients and boundary conditions (Lang et al., 2004).

As said above, hydraulic reconstruction involves a great deal of assumptions about input data; therefore, sensitivity analyses should be performed to delimit the effect of a given variation in input data on the results, that is, to estimate the error of the results.

\subsection{Hydrological reconstruction}

The objective of the hydrological reconstruction is the hyetograph of the rainfall that caused the flood.

A hydrological model summarizes the characteristics of the catchment that conform its hydrological response, that is, the way it transforms rainfall into runoff and, eventually, into river flow. In other words, a model tries to quantify the hydrological processes occurring between the rain precipitation and the water exiting the catchment through its outlet.

There are three main types of hydrological models: the stochastic ones, the empirical ones and the physics-based ones. Firstly, the stochastic models use large amounts of

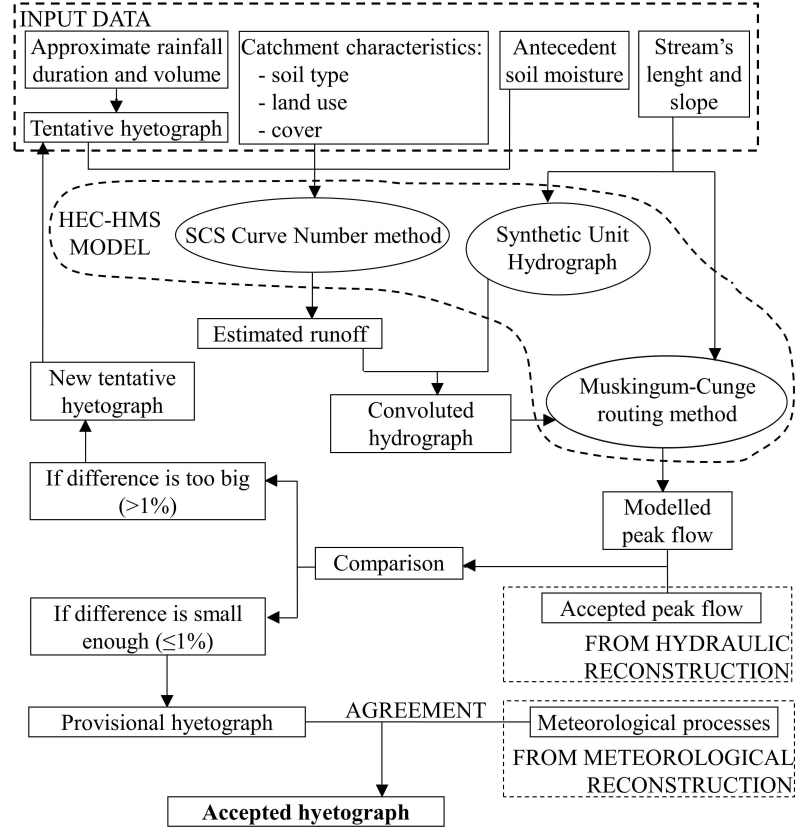

Figure 6. Iterative procedure used in the hydrological reconstruction of hyetographs (modified from Balasch et al., 2010b).

paired rainfall-flow data to calculate non-dimensional parameters that describe the catchment's hydrological response; an example is GR4J (Perrin et al., 2003). Secondly, the empirical models use simplified empirical equations and methods (such as the Curve Number method; NRCS, 2007). Finally, the physics-based models use complex physics equations and need a lot of precise field measurements; an example is InHM (VanderKwaak and Loague, 2001).

Hydrological models can also be classified according to their treatment of space as well: lumped models calculate processes at the catchment or subcatchment scale (e.g. HECHMS), whereas distributed models do it in smaller areas and afterwards aggregate the results (e.g. r.water.fea, Vieux et al., 2004).

Due to the scarcity of data typically found outside heavily instrumented catchments and for the sake of simplicity, we use HEC-HMS, an empirical, lumped hydrological model (USACE, 2010). HEC-HMS allows the user to choose among an array of different empirical methods for each one of these three hydrological processes: runoff generation, transformation of runoff into river flow, and river flow routing. For each of these processes we chose, systematically and respectively, the SCS Curve Number, the Synthetic Unit Hydrograph and the Muskingum-Cunge methods, because of their simplicity of use, their moderate requirements in input data and their being generally accepted and commonly used (NRCS, 2007).

Similarly as in the hydraulic reconstruction, the calculation procedure is iterative, because the result (that is, the hyetograph) is, actually, an input datum required by the model (Fig. 6). Therefore, a tentative hyetograph must be 
built using the available historical information about the rain event, such as, its duration, the affected area (in which subcatchments it rained and in which it did not), or indications that can lead to a rough estimation of the rainfall volume. Besides this tentative hyetograph, the model needs input data describing the catchment (or subcatchments) hydrological characteristics, such as soil type, land use, antecedent soil moisture and the stream's slope.

The result of the hydrological model (the peak flow) is then compared to the one calculated in the hydraulic reconstruction; if the two are similar enough, the tentative hyetograph is provisionally accepted. If this provisional hyetograph agrees with the meteorological processes found in the meteorological reconstruction, it is definitely accepted.

The kind of inputs variables and empirical methods used have a great degree of uncertainty (Willems, 2001), all the more in the case of historical floods, because the data have to be adapted from present-day values to the estimated ones at the time of the studied flood. Thus, a calibration of the model should be made whenever measured data are available. For the same reason, a sensitivity analysis should be performed once the hydrological reconstruction is done in order to estimate the real amount of uncertainty in the results.

\subsection{Meteorological reconstruction}

The objective of this reconstruction is the analysis of the meteorological processes before and during the rain event that caused the flood. This analysis has two direct applications: the estimation of the antecedent soil moisture condition (an input required in the hydrological reconstruction) and the classification of floods according to their meteorological causes, which can, eventually, become a useful tool in flood forecasting.

The meteorological reconstruction is done on three different levels depending on the data availability or, more specifically, on the horizontal, vertical and temporal resolution of the available data, which decreases as we move back in time. Also, there are three different periods according to the quality of the available data, and a different level of reconstruction is applied to the floods in each one of them:

1. Events that occurred since ca. 1750 (available data: surface temperature, pressure and precipitation recorded at several European locations): since the second half of the 18th century, several observatories in Europe have recorded surface temperature and pressure. Some of them additionally recorded accumulated precipitation. Surface temperature and pressure records are used to analyse the synoptic conditions at a regional scale and to calculate zonal pressure indices (Luterbacher et al., 2002).

2. Events that occurred since 1871 (available data: 20th Century Reanalysis data from NOAA). Surface and upper-level meteorological charts since 1871 from the reanalysis made by the Earth System Research Laboratory of the National Oceanic and Atmospheric Administration (NOAA; Kalnay et al., 1996) are used to estimate the synoptic conditions of each episode: temperature, atmospheric circulation at different vertical levels, and precipitation estimates.

Additionally, the reanalysis data allow us to calculate several parameters related to the convection intensity, such as the Vertical, Cross and Total Totals indices (Miller, 1972), the $K$ index (George, 1960), the Humidity index (Litynska et al., 1976), the Ko index (Andersson et al., 1989), the Lifted Index (LI; Galway, 1956), the Integrated Convective Available Potential Energy (ICAPE; Mapes, 1993; Doswell and Rasmussen, 1994), the Vorticity Generating Parameter (Rassmussen et al., 1998), the difference between the LCL and LFC, the wind shear between surface and 1, 3 and $6 \mathrm{~km}$ height, among others. In addition, the reanalysis data can be used to obtain information about wind field, moisture, and column of precipitable water.

3. Events that occurred since ca. 1960 (available data global models with larger resolution and mesoscale numerical simulations): finally, for more recent events, version 3.3 of the WRF-ARW mesoscale model (Skamarock et al., 2008) is used at high horizontal resolution (up to approximately $1 \mathrm{~km}$ ) to analyse synoptic, mesoscale and local conditions during the floods. The initial and boundary conditions to run the model are obtained from the ECMWF model reanalysis up to $0.25^{\circ}$ horizontal resolutions.

\section{Concluding remarks}

The Prediflood database meets the internationally accepted scientific standards. It is, therefore, a repository of reliable and contrasted information that allows accurate flood analysis. Actually, some of its data have already been successfully used in several flood reconstructions; at the same time, the density of the information in both space and time gives this database a great potentiality in time series analysis.

The Prediflood database is in a permanent state of data incorporation. The present-day information comes from the search of about $5 \%$ of documentary sources with interesting information in Catalonia. Consequently, the drawing of any kind of conclusion is premature. Firsts steps are showing that this research with an interdisciplinary framework is possible in the Spanish context and may be fruitful.

This effort is focused not only on quantity of flood events detected, but also on qualitative aspects, putting especial effort into increasing the reliability and detail of information collected to be subjected to hydraulic, hydrological, meteorological reconstructions, as is made for climatic reconstruction in recent years. This produces a substantial improvement 
of quality and quantity of obtainable results: quality because results are more credible; quantity because spatio-temporal scales covered by reconstructions can be enlarged.

For the future, the most immediate objectives for the Prediflood database are:

- to enlarge the percentage of primary sources worked for flood events reconstruction;

- to explore the archives of presently poorly represented areas or flood events that appear interesting but are not known about well enough.

At present, the Prediflood database is a heterogeneous amount of information well catalogued. Potentiality can be tested immediately. Large or severe events can be easily identified and classified. Quantified information allows basic reconstruction of hydraulic and hydrological processes.

Atmospheric conditions producing strong rainfall events and floods would be better analysed with an enlargement of the number of cases for the NE Iberian Peninsula. Detection and definition of patterns of the synoptic conditions, and comparison between different flood events will improve understanding of the atmospheric processes producing floods.

When long data series become available, after the homogenization required by the different demographic and social contexts existing for different flood events, an improved climatic variability analysis related to flood events will be possible. Application for meteorological forecasting services and flood risk managers will be strongly positive.

Acknowledgements. Research supported by PREDIFLOOD Project, CGL2012-35071, Programme I+D+i, Spanish Ministry of Economy and Competitiveness. One author has a predoctoral grant supported by University of Lleida. Authors thanks support and data provided by Catalan Geological Institute (IGC) and Catalan Water Agency (ACA).

Edited by: A. Kiss

\section{References}

Alberch, R., Freixes, P., Massanas, E., and Miró, J.: Girona: Ponts, rius, aiguats, Ajuntament de Girona, Girona, 1982 (in Catalan).

Almela, F.: Las riadas del Turia (1321-1949), Ayuntamiento de Valencia, Valencia, 1957 (in Spanish).

Andersson, T., Andersson, M., Jacobsson, C., and Nilsson, S.: Thermodynamic indices for forecasting thunderstorms in southern Sweden, Meteorol. Mag. 116, 141-146, 1989.

Balasch, J. C., Ruiz-Bellet, J. L., Tuset, J., and Martín de Oliva, J.: Reconstruction of the 1874 Santa Tecla's rainstorm in Western Catalonia (NE Spain) from flood marks and historical accounts, Nat. Hazards Earth Syst. Sci., 10, 2317-2325, doi:10.5194/nhess-10-2317-2010, 2010a.
Balasch, J. C., Tuset, J., Ruiz-Bellet, J. L.: Reconstructing the 1874 Santa Tecla flash flood in the Ondara River (Ebro Basin, NE Spain), Adv. Geosci., 26, 45-48, 2010b, http://www.adv-geosci.net/26/45/2010/.

Balasch, J. C., Ruiz-Bellet, J. L., and Tuset, J.: Historical flash floods retromodelling in the Ondara River in Tàrrega (NE Iberian Peninsula), Nat. Hazards Earth Syst. Sci., 11, 3359-3371, doi:10.5194/nhess-11-3359-2011, 2011.

Barrera, A. and Cunillera, J.: Primer Informe sobre la Generació d'escenaris Climàtics Regionalitzats per a Catalunya Durant el Segle XXI, Servei Meteorològic de Catalunya, Departament de Territori i Sostenibilitat, Generalitat de Catalunya, Barcelona, 95 pp., available at: http://www20.gencat.cat/docs/meteocat/ Continguts/Climatologia/Canviclimatic/static_files/informe_ escenaris_SMC-JUN2011.pdf (last access: 3 July 2011) (in Catalan).

Barrera, A., Llasat, M. C., and Barriendos, M.: Estimation of extreme flash flood evolution in Barcelona County from 1351 to 2005, Nat. Hazards Earth Syst. Sci., 6, 505-518, doi:10.5194/nhess-6-505-2006, 2006.

Barriendos, M. and Martin-Vide, J.: Secular Climatic Oscillations as Indicated by Catastrophic Floods in the Spanish Mediterranean Coastal Area (14th-19th Centuries), Climatic Change, 38, 473-491, 1998.

Barriendos, M. and Pomés, J.: L'aigua a Mataró, Inundacions i recursos hídrics (ss. XVIII-XX), Caixa d'Estalvis Laietana, Mataró, 1993 (in Catalan).

Barriendos, M. and Rodrigo, F. S.: Study on historical flood events of spanish rivers using documentary data, Hydrolog. Sci. J., 51, 765-783, 2006.

Bentabol, H.: Las aguas de España y Portugal, Vda. e Hijos de M Tello, Madrid, 2nd ed., 1900 (in Spanish).

Blasco, J.: Las avenidas del Ebro, Crecidas verdaderamente extraordinarias, 1261-1959, Librería General, Col. "La Cadiera", 139 , Zaragoza, 1959 (in Spanish).

Brázdil, R., Glaser, R., Pfister, C., Antoine, J. M., Barriendos, M., Camuffo, D., Deutsch, M., Enzi, S., Guidoboni, E., and Rodrigo, F. S.: Flood events of selected rivers of Europe in the Sixteenth Century, Climatic Change, 43, 239-285, 1999.

Brázdil, R., Kundzewicz, Z. W., Benito, G.: Historical hydrology for studying flood risk in Europe, Hydrolog. Sci. J., 51, 739-764, 2006.

Camuffo, D. and Enzi, S.: The analysis of two bi-millennial series, Tiber and Po river floods, in: Climatic Variations and Forcing Mechanisms of the Last 2000 Years, edited by: Jones, P. D., Bradley, R. S., and Jouzel, J., Springer Verlag, NATO ASI Series, Vol. 141, 433-450, 1996.

Catálogo Nacional de Inundaciones Históricas: 2006-2010, digitized format: 5 CDs, vol. 1 (2006, Duero and Segura Basins), vol. 2 (2007, Júcar and Tajo Basins), vol. 3 (2008, Ebro and Guadalquivir Basins), vol. 4 (2009, Norte and Galicia Basins), vol. 5 (2010, Guadiana and Sur Basins), Dirección General de Protección Civil y Emergencias, Ministerio del Interior, Madrid, 2006-2010 (in Spanish)

Champion, M.: Les Inondations en France depuis le VIe siècle jusqu'à nos jours, recherches et documents contenant les relations contemporaines, les actes administratifs, les pièces officielles, etc. de toutes les époques, avec détails historiques sur les quais, ponts, digues, chaussées, levées, etc., publiés, annotés 
et mis en ordre par M. Maurice Champion., 6 volumes, V. Dalmont, Paris, 1858-1864 (in French).

Chía, J.: Inundaciones de Gerona, Relación histórica de las más notables inundaciones que han causado en esta ciudad las avenidas de los ríos Ter, Oñar, Güell y Galligans desde la ocurrida en 28 de diciembre de 1367 hasta las que tuvieron lugar en 8 y 11 de octubre del corriente año de 1861, Paciano Torres, Girona, 1861 (in Spanish).

Chow, V. T.: Open-channel hydraulics, McGraw-Hill, New York, 680 pp., 1959.

Codina, J.: Inundacions al Delta del Llobregat, R. Dalmau, Col. "Episodis de la Història", 147-148, Barcelona, 1971 (in Catalan).

Couchoud, R.: Hidrología histórica del Segura, Efemérides hidrológica y fervorosa recopilada y escrita por Dr. R. Couchoud, Centro de Estudios Hidrográficos, Madrid, 1965 (in Spanish).

Doswell, C. A. III and Rasmussen, E. N.: The effect of the neglecting the Virtual temperature correction on CAPE calculations, Weather Forecast., 9, 625-629, 1994.

EEA, European Environment Agency: Mapping the impacts of natural hazards and technological accidents in Europe. An overview of the last decade, EEA Technical report, no. 13/2010, 146 pp., 2010.

Galway, J. G.: The lifted index as a predictor of latent instability, B. Am. Meteorol. Soc., 43, 528-529, 1956.

Gaume, E., Bain, V., Bernardara, P., Newinger, O., Barbuc, M., Bateman, A., Blaškovicová, L., Blöschl, G., Borga, M., Dumitrescu, A., Daliakopoulos, I., Garcia, J., Irimescu, A., Kohnova, S., Koutroulis, A., Marchi, L., Matreata, S., Medina,V., Preciso, E., Sempere-Torres, D., Stancalie, G., Szolgay, J., Tsanis, I., Velasco, D., and Viglione, A.: A compilation of data on European flash floods, J. Hydrol., 367, 70-78, 2009.

George, J. J.: Weather Forecasting for Aeronautics, Academic Press, 673 pp., 1960.

Glaser, R.: Data and Methods of Climatological Evaluation in Historical Climatology, Hist. Soc. Res., 21, 56-88, 1996.

Grimalt, M.: Aproximació a una geografia del risc a Mallorca. Les inundacions, 3 vol., Ph.D. thesis, Departament de Ciències de la Terra, Universitat de les Illes Balears, Palma, 1988 (in Catalan).

Grimalt, M.: Geografia del risc a Mallorca. Les Inundacions. Institut d'Estudis Baleàrics, Palma, 1992 (in Catalan).

Hernández, A.: Inundaciones de la Huerta de Murcia, Juicio sobre su frecuente repetición de pocos años a esta parte, sus terribles desastres, sus causas y remedios, El Diario, Murcia, 1885 (in Spanish).

Iber: Hydraulic Reference Manual Iber v1.0, Ministerio de Medio Ambiente y Medio Rural y Marino, 56 pp., 2010.

Iglésies, J.: L'aiguat de santa Tecla (23 de setembre de 1874). Col. "Episodis de la Història", Dalmau, Barcelona, 64 pp., 1971 (in Catalan).

IPCC: Summary for policymakers, in: Climate Change 2014: Impacts, Adaptation, and Vulnerability. Part A: Global and Sectoral Aspects. Contribution of Working Group II to the Fifth Assessment Report of the Intergovernmental Panel on Climate Change, edited by: Field, C. B., Barros, V. R., Dokken, D. J., Mach, K. J., Mastrandrea, M. D., Bilir, T. E., Chatterjee, M., Ebi, K. L., Estrada, Y. O., Genova, R. C., Girma, B., Kissel, E. S., Levy, A. N., MacCracken, S., Mastrandrea, P. R., and White, L. L.,
Cambridge University Press, Cambridge, UK and New York, NY, USA, 1-32, 2014.

Kalnay, E., Kanamitsu, M., Kistler, R., Collins, W., Deaven, D., Gandin, L, Iredell, M., Saha, S., White, G., Woollen, J., Zhu, Y., Leetmaa, A., Reynolds, R., Chelliah, M., Ebisuzaki, W., Higgins, W., Janowiak, J., Mo, K. C., Ropelewski, C., Wang, J., Jenne, R., and Joseph, D.: The NCEP/NCAR Reanalysis 40-year Project, B. Am. Meteorol. Soc., 77, 437-471, 1996.

Kovats, S. and Valentini, R.: IPCC WGII AR5, IPCC Working Group II, Technical Support Unit, Stanford, USA, Chapter 23: Europe, 93 pp., 2014.

Lang, M., Fernández-Bono, J. F., Recking, A., Naulet, R., and GrauGimeno, P.: Methodological guide for paleoflood and historical peak discharge estimation, in: Systematic Paleoflood and Historical Data for the Improvement of Flood Risk Estimation. Methodological Guidelines, edited by: Benito, G. and Thorndycraft, V. R., Centro de Ciencias Medioambientales, Madrid, 43-53, 2004.

Litynska, Z., Parniewicz, J., and Pinkowski, H.: The Prediction of Air Mass Thunderstorms and Hials, WMO, Geneve, 450, 128 130, 1976.

Llasat, M. C., Rigo, T., and Barriendos, M.: The "Montserrat-2000" flash-flood event: a comparison with the floods in the Northeastern Iberian Peninsula since the 14th century, Int. J. Climatol., 23, 453-469, 2003.

Llasat, M. C., Barriendos, M., Barrera, A., and Rigo, T.: Floods in Catalonia (NE Spain) since the 14th Century, Climatological and meteorological aspects from historical documentary sources and old instrumental records, J. Hidrol., 313, 16-31, 2005.

López Gómez, A.: Las lluvias catastróficas mediterráneas. Estudios Geográficos, Madrid, 44, 11-30, 1983 (in Spanish).

Luterbacher, J., Xoplaki, E., Dietrich, D., Rickli, R., Jacobeit, J., Beck, C., Gyalistras, D., Schmutz, C., and Wanner, H.: Reconstruction of sea-level pressure fields over the eastern North Atlantic and Europe back to 1500, Clim. Dynam. 18, 545-561, 2002.

Mapes, B. E.: Gregarious tropical convection, J. Atmos. Sci., 50, 2026-2037, 1993.

Marqués, J.: Girona Vella/1, Ajuntament de Girona, Girona, 1979a.

Marqués, J.: Girona Vella/2, Ajuntament de Girona, Girona, 1979b.

Miller, R. C.: Notes on analysis and severe storm forecasting procedures of the Air Force Global Weather Central. Tech. Report 200(R), Headquarters, Air Weather Service, Scott Air Force Base, IL 62225, 190 pp., 1972.

NRCS (Natural Resources Conservation Service): National Engineering Handbook, US Departement of Agriculture, 2007.

Perrin, C., Michel, C., and Andréassian, V.: Improvement of a parsimonious model for streamflow simulation, J. Hydrol., 279, 275289, 2003.

Pfister, C.: Wetternachhersage, 500 Jahre Klimavariationen und Naturkatastrophen, Verlag Paul Haupt, Bern, 1998 (in German).

Rasmussen, E. N. and Blanchard, D. O.: A baseline climatology of sounding derived supercell and tornado forecast parameters, Weather Forecast., 13, 1148-1164, 1998.

Ruiz Villanueva, V., Bladé, E., Díez-Herrero, A., Bodoque, J. M., and Sánchez-Juny, M.: Two-dimensional modelling of large wood transport during flash floods, Earth Surf. Proc. Land., 39, 438-449, 2013.

Skamarock, W., Klemp, J. B., Dudhia, J., Gill, D. O., Barker, D., Duda, M. G., Huang, X.-Y., and Wang, W.: A description of the 
advanced research WRF version 3, NCAR, Boulder, USA, Tech. Rep. NCAR/TN475+STR, NCAR, 2008.

SNCZI, Sistema Nacional de Cartografía de Zonas Inundables, available at: http://www.magrama.gob.es/ca/agua/temas/ gestion-de-los-riesgos-de-inundacion/snczi/ (last access: 3 July 2014), 2010 (in Spanish).

Thorndycraft, V., Barriendos, M., Benito, G., Rico, M., and Casas, A.: The catastrophic floods of AD 1617 in Catalonia (NE Spain) and their climatic context, Hydrolog. Sci. J., 51, 899-912, 2006.

US Army Corps of Engineers (USACE): HEC-RAS River Analysis System: Hydraulic Reference Manual. US Army Corps of Engineers, Hydrologic Engineering Center, Davis, CA, USA, 2008.

US Army Corps of Engineers (USACE): Hydrology Modeling System HEC-HMS User's Manual. US Army Corps of Engineers, Hydrologic Engineering Center, Davis, CA, USA, 2010.
VanderKwaak, J. E. and Loague, K.: Hydrologic-response simulations for the R-5 catchment with a comprehensive physics-based model, Water Resour. Res., 37, 999-1013, 2001.

Vieux, B. E., Cui, Z., and Gaur, A.: Evaluation of a physics-based distributed hydrologic model for flood forecasting, J. Hydrol., 298, 155-177, 2004.

Wetter, O., Pfister, C., Weingartner, R., Luterbacher, J., Reist, T., and Trösch, J.: The largest floods in the High Rhine basin since 1268 assessed from documentary and instrumental evidence, Hydrolog. Sci. J., 56, 733-758, 2011.

Willems, P.: Stochastic description of the rainfall input errors in lumped hydrological models, Stoch. Env. Res. Risk A., 15, 132$152,2001$. 